\title{
TRANSMISI HADIS DAN KONTRIBUSINYA DALAM PEMBENTUKAN JARINGAN KEILMUAN DALAM ISLAM
}

\author{
Saifuddin \\ Jurusan Tafsir Hadis Fakultas Ushuluddin IAIN Antasari, Jln. Jend. \\ Ahmad Yani, \\ Km. 4,5 Banjarmasin, Telp. (0511) 3266593
}

\begin{abstract}
Abstraksi: Transmisi dan difusi ilmu-ilmu keislaman sepanjang sejarahnya hampir selalu melibatkan semacam "jaringan ulama". Proses terbentuknya jaringan ulama ini tidak dapat dipisahkan dari perkembangan tradisi Islam sendiri. Tidak diragukan hadis merupakan cabang ilmu yang secara khusus memiliki peran signifikan. Dalam studi dan transmisi hadis terdapat sebuah tradisi keilmuan yang dikenal dengan "al-rihlat fî thalab al-hadîts". Selain itu, sistem jaringan sanad (isnâd) yang sangat dipentingkan dalam transmisi hadis juga mempunyai pengaruh nyata dalam pembentukan jaringan ulama.
\end{abstract}

Kata kunci: transmisi hadis, rihlah, isnâd, jaringan ulama

\section{PENDAHULUAN}

Studi tentang transmisi hadis (riwâyat al-hadits) berikut kontribusinya dalam proses pembentukan jaringan ulama dan keilmuan dalam Islam menjadi salah satu topik pembicaraan yang menarik perhatian. Proses historis terbentuknya jaringan ulama dan keilmuan dalam Islam bagaimanapun tidak dapat dipisahkan dari perkembangan awal tradisi Islam sendiri, khususnya yang berkaitan erat dengan proses penyebaran dan transmisi hadis. ${ }^{1}$

Transmisi hadis yang dimaksudkan di sini adalah kegiatan penerimaan dan penyampaian hadis, serta penyandaran hadis itu kepada para periwayatnya dengan lafal-

\footnotetext{
1 Azyumardi Azra dan Oman Fathurrahman, "Jaringan Ulama", dalam Taufik Abdullah et al. (ed.), Ensiklopedi Tematis Dunia Islam, (Jakarta: Ichtiar Baru Van Hoeve, 2005), jilid V, h. 105-106.
} 
lafal tertentu. ${ }^{2}$ Dengan demikian, orang yang telah menerima hadis dari seorang periwayat, tetapi dia tidak menyampaikannya kepada orang lain, maka dia tidak dapat disebut sebagai orang yang telah melakukan periwayatan hadis. Begitupun sekiranya orang tersebut menyampaikan hadis yang telah diterimanya kepada orang lain, tetapi ketika menyampaikan hadis itu dia tidak menyebutkan rangkaian para periwayatnya, maka dia

2 Pengertian transmisi atau periwayatan (al-riwâyah), menurut para sarjana hadis, dapat dilihat dalam Jalâl al-Dîn al-Suyûthiy, Tadrîb alRâwiy fî Syarh Taqrîb al-Nawâwiy,

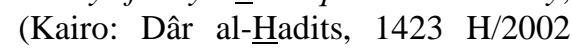
M), h. 24-25; Nûr al-Dîn 'Itr, Manhaj

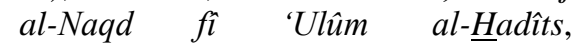
(Damaskus: Dâr al-Fikr, 1418 H/1997 M), h. 188; Nûr al-Dîn 'Itr, Manâhij alMuhadditsîn al-'Âmmah, (Damaskus: Maktabat Dâr al-Furûq, 1420 H/1999 M), h. 34; Muhammad ibn Muhammad Abû Syuhbah, al-Wasîth fì 'Ulûm wa Mushthalah al-Hadîts, (Kairo: Maktabat al-Sunnah, 1427 H/2006 M), h. 41; Ahmad 'Umar Hâsyim, Qawâ 'id Ushûl al-Hadîts, (Beirut: Dâr al-Fikr, t.th.), h. 230; Muhammad Jamâl al-Dîn al-Qâsimiy, Qawấid al-Tahdîts min Funûn Mushthalah al- $\underline{H}$ adîts, (t.t.: Îsâ al-Halabiy, 1353 H), h. 75; M. Syuhudi Ismail, Kaedah Kesahihan Sanad Hadis: Telaah Kritis dan Tinjauan dengan Pendekatan Ilmu Sejarah, (Jakarta: Bulan Bintang, 1415 H/1995 M), h. 23. juga tidak dapat dinyatakan sebagai orang yang telah melakukan periwayatan hadis. ${ }^{3}$ Jadi, dalam transmisi hadis setidaknya tercakup tiga unsur kegiatan: (1) menerima hadis dari periwayat sebelumnya; (2) menyampaikan hadis kepada orang lain; dan (3) ketika menyampaikan hadis itu, matarantai periwayatnya juga disebutkan. ${ }^{4}$

Dalam proses transmisi hadis tersebut terjalin hubungan yang kompleks dan saling silang antara guru dan murid, sesama guru, ataupun sesama murid, dan membentuk semacam "jaringan"5 yang dalam disiplin

${ }^{3}$ Nûr al-Dîn 'Itr, Manhaj alNaqd, h. 188; Nûr al-Dîn 'Itr, Manâhij al-Muhadditsîn, h. 34; M. Syuhudi Ismail, Kaedah Kesahihan, h. 23.

${ }^{4}$ M. Syuhudi Ismail, Kaedah Kesahihan, h. 23-24. Bandingkan dengan Ibrâhîm Dasûkiy al-Syahâwiy,

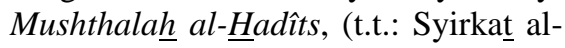
Thibâ'at al-Fanniyyat al-Muttahidah, 1971), h. 68.

5 Istilah "jaringan" sejauh ini telah banyak digunakan dalam berbagai cabang keilmuan. Setidaknya ada beberapa komponen dan prinsip-prinsip mendasar yang memungkinkan "sesuatu" dapat dikategorikan sebagai sebuah "jaringan". Komponenkomponen dimaksud adalah: (1) sekumpulan orang, objek, atau kejadian; minimal berjumlah tiga satuan-yang berperan sebagai terminal (pemberhentian). Biasanya 
ilmu hadis dikenal dengan sanad (isnâd). Hubungan-hubungan seperti itu pada gilirannya juga terbentuk dalam berbagai cabang disiplin ilmu keislaman lainnya. Tulisan berikut ini berusaha mengeksplorasi lebih lanjut tentang perjalanan historis penyebaran dan transmisi hadis, dan sekaligus menelusuri

direpresentasikan dengan titik-titik, yang dalam peristilahan jaringan disebut sebagai aktor atau node; (2) seperangkat ikatan yang menghubungkan satu titik ke titik-titik lainnya dalam jaringan; (3) arus, yang dalam diagram digambarkan dengan 'anak panah'. Sedangkan prinsipprinsip yang mendasar bagi sebuah jaringan adalah: (1) ada pola tertentu. Sesuatu yang mengalir dari titik yang satu ke titik-titik lainnya, saluran atau jalur yang harus dilewati tidak terjadi secara acak, artinya bisa memilih sekehendaknya; (2) rangkaian ikatanikatan itu menyebabkan sekumpulan titik-titik yang ada bisa diketegorikan sebagai satu kesatuan yang berbeda dengan satu kesatuan yang lain; (3) ikatan-ikatan yang menghubungkan satu titik ke titik-titik lainnya harus bersifat permanen (ada unsur waktu, yaitu masalah 'durasi'); (4) ada hukum yang mengatur saling keterhubungan masing-masing titik di dalam jaringan, ada hak dan kewajiban yang mengatur masing-masing titik (anggota), hubungan titik yang satu terhadap titiktitik yang lain, hubungan semua titik dengan titik-titik pusat dan sebagainya. Lihat Ruddy Agusyanto, Jaringan Sosial dalam Organisasi, (Jakarta: Raja Grafndo Persada, 2007), h. 7-13. bagaimana arus penyebaran dan transmisi hadis telah memberikan kontribusi nyata bagi terbentuknya jaringan ulama dan keilmuan dalam Islam.

\section{PEMBAHASAN}

\section{Penyebaran dan Transmisi Hadis: Perspektif Historis}

Sejarah penyebaran dan transmisi hadis telah melewati serangkaian fase historis yang panjang dan rumit. Dimulai pada periode kenabian, arus penyebaran dan transmisi hadis mengalami pertumbuhan yang sangat pesat pada dua ratus tahun pasca hijrah Nabi. Meski terjadi beberapa pemalsuan hadis yang dilandasi oleh berbagai motif, paling tidak mendekati akhir abad II H aktivitas tersebut telah sepenuhnya berkembang menjadi salah satu cabang disiplin ilmu keislaman yang sangat penting. Disiplin ilmu tersebut kemudian dikenal sebagai 'ulûm al-hadîts dengan perangkat metodologinya yang unik untuk menentukan keotentikan transmisi hadis. ${ }^{6}$

${ }^{6}$ Munawar Ahmad Anees dan Alia N. Athar, Guide to Sira and Hadith Literature in Western 
Perkembangan awal penyebaran dan transmisi hadis, dengan demikian, dapat dikatakan sudah dimulai sejak periode kenabian. Dalam berbagai kesempatan Nabi saw. menyampaikan hadisnya dan kemudian direkam oleh para sahabatnya. Muhammad Mustafa Azami mencatat bahwa Nabi saw. menyampaikan hadisnya melalui tiga kategori: (1) pengajaran verbal (verbal teaching); (2) media tertulis (writing medium); dan (3) demonstrasi praktis (practical demonstration). ${ }^{7}$ Hadis tersebut kemudian direkam oleh para sahabat juga melalui tiga cara: (1) hafalan (memorizing); (2) tulisan (recording); dan praktik (through practise). ${ }^{8}$ Selama periode kenabian, proses penyebaran dan

\footnotetext{
Language, (London: Manshell Publishing Limited, 1986), h. xii.

${ }_{7}$ Muhammad Mustafa Azami, Studies in Hadith Methodology and Literature, (Indianapolis: Islamic Teaching Center, 1997), h. 9-10. Justice Muhammad Taqi Usmani dalam kasus yang sama menyebutkan empat kategori, yakni: (1) hafalan; (2) diskusi; (3) praktik; dan (4) tulisan. Lihat Justice Muhammad Taqi Usmani, The Authority of Sunnah, (New Delhi: Kitab Bhavan, t.th.), h. 83-93.

${ }_{8}^{8}$ Muhammad Mustafa Azami, Studies in Hadith Methodology, h. 1314.
}

transmisi hadis, selain terkonsentrasi di seputar wilayah Madinah, untuk sebagian juga sudah mulai merambah ke sejumlah daerah di sekitar Arabia. Tersebarnya hadis sepanjang periode tersebut setidaknya didorong oleh beberapa faktor berikut. Pertama, gencarnya Nabi saw. menyampaikan dakwahnya dan menyebarkan Islam ke berbagai penjuru dan kabilah Arab. Kedua, karakteristik Islam dan sistem ajarannya yang baru, telah membuat orang bertanyatanya tentang aturan-aturan hukum, tentang pembawa agama itu, dan masalah lainnya. Sebagian mereka yang pernah menerima dakwah, kemudian menghadap Nabi saw., bertanya tentang Islam, dan menyatakan diri masuk Islam. Selanjutnya mereka kembali ke kaumnya untuk menyampaikan apa yang telah dilihat dan mengabarkan yang apa yang pernah didengarnya. Ketiga, giatnya para sahabat mempelajari hadis, menghafal, dan menyampaikannya kepada orang lain. Keempat, peranan istri-istri Nabi saw. juga tidak kecil dalam menyampaikan ajaran Islam dan menyebarkan hadis kepada para perempuan muslimah. Kelima, para sahabat perempuan diakui 
mempunyai andil besar dalam memelihara hadis dan menyebarkannya kepada orang lain.

Keenam, pengiriman para utusan Nabi saw. dan para gubernur muslim yang dipercaya untuk menyampaikan surat-surat tentang ajakan memeluk Islam kepada sejumlah kepala negara dan pemimpin kabilah. Ketujuh, peristiwa penaklukan kota Makkah (8 H) telah menjadi momentum penting pertemuan Nabi saw. dengan kaum muslim dari berbagai penjuru negeri. Mereka pun berkesempatan untuk menanyakan langsung kepada Nabi saw. masalahmasalah agama dan syariat Islam. Kedelapan, kedatangan para delegasi dari kabilahkabilah Arab pasca peristiwa penaklukan kota Makkah berperan penting dalam penyebaran hadis ke berbagai pelosok negeri. Para delegasi datang kepada Nabi saw., diajarkan kepada mereka agama Islam, lalu kembali ke kabilahnya untuk menyampaikan ajaran agama tersebut. Kesembilan, peristiwa haji wadak $(10 \mathrm{H})$ juga memiliki pengaruh besar dalam penyebaran hadis ke sejumlah kabilah Arab. Dalam peristiwa itu Nabi saw. memberikan khotbah yang didengar oleh puluhan ribu orang, kemudian mereka menyampaikannya kembali kepada para anggota kabilah di berbagai penjuru negari. $^{9}$

Kegiatan penyebaran dan transmisi hadis semakin meluas sejalan dengan derasnya ekspansi komunitas muslim ke luar batas-batas wilayah Arabia. Dalam satu atau beberapa dasawarsa setelah Nabi saw. wafat, Islam mulai meluas ke berbagai wilayah, seperti Afghanistan, Iran, Syria, Irak, Mesir, dan Lybia. Seiring dengan itu, tersebar pula hadis ke berbagai wilayah kekuasaan Islam. Akibatnya, peredaran hadis tidak hanya terkonsentrasi di sekitar Madinah. Boleh jadi beberapa hadis tertentu sudah diperkenalkan para sahabat ketika menjelajahi Irak, Mesir, atau wilayah-wilayah lainnya. ${ }^{10}$

9 Muhammad 'Ajjâj alKhathîb, Ushûl al-Hadîts: 'Ulûmuhu wa Mushthalahuhu, (Beirut: Dâr alFikr, 1409 H/1989 M), h. 72-78; Muhammad 'Ajjâj al-Khathîb, alSunnat Qabl al-Tadwîn, (Beirut: Dâr al-Fikr, 1401 H/1981 M), h. 69-74.

10 Muhammad Muhammad Abû Zahwu, al-Hadîts wa alMuhadditsûn, (Mesir: Dâr al-Fikr al'Arabiy, 1376 H), h. 100-101; Muhammad Mustafa Azami, Studies in Hadith Methodology, h. 15. 
Penyebaran dan transmisi hadis semakin ekstensif ketika sejumlah besar sahabat berpindah dari Madinah dan kemudian menetap di berbagai wilayah yang ditaklukkan oleh laskar muslim. ${ }^{11}$

Peran generasi sahabat diakui sangat sentral dalam proses penyebaran dan transmisi hadis. Daniel W. Brown mencatat, para sahabat menjadi rantai penghubung yang sangat diperlukan dalam rantai epistemologis antara Nabi saw. dan manusia lainnya. Para sahabat menjadi satu-satunya agen, yang dengan perantaraan mereka pengetahuan andal mengenai diri Nabi saw. (hadis) dan al-Qur'an dapat ditransmisikan. ${ }^{12}$ Artinya, tanpa peran aktif mereka dalam proses perekaman dan transmisi hadis,

11 Muhammad Abû Zahwu,

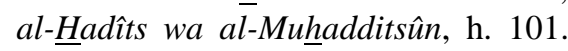
Sebuah studi yang cukup luas dan komprehensif menyangkut penyebaran para sahabat Nabi ke berbagai wilayah Islam dilakukan oleh Fu'ad Jabali dalam disertasi doktoralnya. Lihat Fu'ad Jabali, The Companions of The Prophet: A Geographical Distribution and Political Alignments, (Leiden: Brill, 2003), h. 110-182, 200-513.

12 Daniel W. Brown, Rethinking Tradition in Modern Islamic Thaught, (Cambridge: Cambridge University Press, 1994), h. 85. maka sangat mungkin seluruh jejak hadis akan hilang, tanpa dapat dikenali oleh generasi sesudahnya. Para sahabat sendiri tampaknya cukup antusias menyebarkan hadis kepada masyarakat, dan yang terpenting adalah melalui media pengajaran. Keterlibatan mereka dalam aktivitas itu pada dasarnya dapat dibagi menjadi dua: pertama, kelompok yang mengambil peran pada saat masyarakat membutuhkannya. Rupanya mereka terdorong melakukan tugas itu karena takut ancaman dan dosa menyembunyikan ilmu; kedua, kelompok yang mencurahkan segala jerih payahnya untuk tujuan ini dan biasanya mengajarkan hadis secara teratur. $^{13}$

Selama periode sahabat ini, tepatnya dalam masa pemerintahan al-khulafâ' alrâsyidûn, terjadi perkembangan yang cukup menarik dan penting terkait dengan penyebaran dan transmisi hadis. Perkembangan itu antara lain ditandai dengan: pertama, upaya pembatasan periwayatan hadis; dan kedua, kehati-hatian dalam transmisi hadis, baik ketika menerima

\section{${ }^{13}$ Muhammad Mustafa}

Azami, Studies in Hadith Methodology, h. 15 . 
maupun menyampaikan kembali kepada orang lain. $^{14}$ Upaya pembatasan periwayatan hadis tampaknya didasari oleh sebuah kekhawatiran bahwa orangorang yang banyak meriwayatkan hadis akan dapat tergelincir karena suatu kesalahan atau kelupaan yang menjadikan mereka menyerupai berbuat dusta tentang diri Nabi saw. secara tidak sadar. ${ }^{15}$ Dampak dari kesalahan ini bagaimanapun akan tetap sama dengan yang disengaja sejauh dikaitkan dengan benar tidaknya sebuah hadis. ${ }^{16}$ Karenanya

14 Mannâ' al-Qaththân,

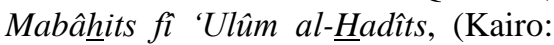
Maktabat Wahbah, 1425 H/2004 M), h. 51-52; Nûr al-Dîn 'Itr, al-Madkhal

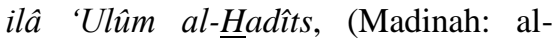
Maktabat al-'Ilmiyyah, 1972), h. 4; Muhammad Abû Zahwu, al- $\underline{\text { Hadîts wa }}$ al-Muhadditsûn, h. 66-69; Nûr al-Dîn 'Itr, Manhaj al-Naqd, h. 52; Nûr alDîn 'Itr, Manâhij al-Muhadditsîn, h. 28-29.

15 Muhammad 'Abd al-'Azîz al-Khûliy, Miftâh al-Sunnat au Târîkh Funûn al-Hadîts, (Beirut: Dâr al-Kutub al-'Ilmiyyah, t.th.), h. 20; Muhammad

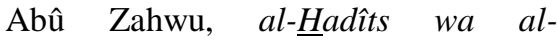
Munadditsûn, h. 67; Nûr al-Dîn 'Itr, Manhaj al-Naqd, h. 52; Nûr al-Dîn 'Itr, Manâhij al-Muhadditsîn, h. 28; Nûr alDîn 'Itr, al-Madkhal, h. 4; Mannâ' alQaththân, Mabâhits fì 'Ulûm, h. 51.

16 Muhammad Mustafa Azami, Manhaj al-Naqd inda alMuhadditsîn: Nas'atuhu wa Târîkhuhu, banyak sahabat yang menahan diri untuk menyampaikan hadis ketika mereka merasa bahwa ingatannya meragukan. ${ }^{17}$ Alasan lain dari upaya pembatasan periwayatan hadis adalah agar para sahabat berkonsentrasi penuh menghafal al-Qur'an dan tidak terganggu oleh urusan lainnya. ${ }^{18}$ Sementara itu, kehatian-hatian dalam transmisi hadis tampaknya juga didasari oleh suatu alasan yang kurang

(Saudi Arabia: Maktabat al-Kautsar, 1410 H/ 1990 M), h. 5. Muhammad Mustafa Azami, Studies in Hadith Methodology, h. 46. Hal itu antara lain didukung oleh pernyataan Anas ibn Mâlik yang menyebutkan bahwa sekiranya dia tidak takut berbuat kekeliruan niscaya semua apa yang telah didengarnya dari Nabi saw. akan dikemukannya kepada orang lain. Dalam laporan lain, Anas ibn Mâlik juga menyatakan bahwa dirinya dilarang untuk meriwayatkan hadis dalam jumlah yang banyak. Lihat 'Abdullâh ibn 'Abd al-Rahmân alDârimiy al-Samarqandiy, Sunan alDârimiy, (Beirut: Dâr al-Fikr, t.th.), jilid I, h. 76-77; Abû al-Husain Muslim ibn al-Hajjâj al-Qusyairiy alNaisâbûriy, Shahîh $\underline{h}$ Muslim, (Kairo: Dâr Ibn al-Haitsam, 1422 H/2001 M), h. 5 .

18 Muhammad Abû Zahwu, al-ㅂadîts wa al-Muhadditsûn, h. 67; Nûr al-Dîn 'Itr, Manhaj al-Naqd, h. 52; Nûr al-Dîn 'Itr, Manâhij alMuhadditsîn, h. 28; Nûr al-Dîn 'Itr, alMadkhal, h. 4. 
lebih sama dengan kasus pembatasan periwayatan hadis. ${ }^{19}$ Penyebaran dan transmisi hadis mengalami peningkatan signifikan ketika memasuki periode sahabat kecil dan tabiin besar yang lebih dikenal dengan "zaman intisyâr al-riwâyat ilâ al-amshâr" (periode penyebaran riwayat ke kota-kota). ${ }^{20}$ Pusat-pusat hadis mulai menyebar di berbagai kota. Selain kota Madinah yang sudah menjadi pusat hadis sejak awal Islam, kota-kota yang merupakan pusat penyebaran hadis adalah Makkah, Kufah, Bashrah, Syria, Mesir, Maghrib, Yaman, Jurjan, Qazwin, dan Khurasan. $^{21}$ Di kota-kota inilah sejumlah besar tabiin mempelajari hadis dari para

19 Muhammad Thâhir alJawâbiy, Juhûd al-Muhadditsîn fî Naqd

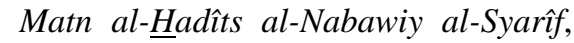
(t.t.: Mu'assasât 'Abd al-Karîm ibn 'Abdillâh, 1406 H/1986 M), h. 104105; Muhammad 'Ajjâj al-Khathîb, Ushûl al-Hadîts, h. 84.

20 Periode ini berlangsung sejak masa awal dinasti Umayyah sampai akhir abad I H. Lihat M. Syuhudi Ismail, Pengantar Ilmu Hadits, (Bandung: Angkasa, 1991), h. 98.

21 Muhammad 'Ajjâj al-

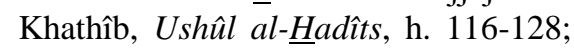
Muhammad 'Ajjâj al-Khathîb, alSunnat Qabl al-Tadwîn, h. 164-175; Muhammad Abû Zahwu, al- $\underline{\text { Hadîts } w a}$ al-Muhadditsûn, h. 101-107. sahabat yang mereka temui. Jika melihat populasi tabiin yang jumlahnya jauh lebih besar dibandingkan generasi sahabat, maka dapat dipastikan bahwa kegiatan penyebaran dan transmisi hadis juga mengalami peningkatan. Apalagi pembatasan periwayatan hadis selama periode tabiin tidak lagi menonjol.

Sejak pertengahan abad II $\mathrm{H}$, penyebaran dan transmisi hadis mengalami perkembangan yang lebih pesat. Para ulama sangat giat meriwayatkan hadis dan kemudian menyusunnya dalam karya-karya kompilasi hadis yang lebih sistematis. Di antara mereka yang paling menonjol adalah: 'Abd al-Malik ibn 'Abd al-'Azîz ibn Juraij (w. 150 H), Muhammad ibn Ishâqq (w. $151 \mathrm{H}$ ), Ma'mar ibn Râyid (w. $153 \mathrm{H}$ ), Sa'îd ibn Abî 'Arûbah (w. $156 \mathrm{H}$ ), 'Abd alRahmân ibn 'Amr al-Auzâ'iy (w. $156 \mathrm{H}$ ), Muhammad ibn 'Abd al-Rahmân ibn Abî Dzi'b (w. 158 H), al-Rabî' ibn Shabîh (w. 160 H), Sufyân al-Tsauriy (w. $161 \mathrm{H}$ ), Hammâd ibn Salamah (w. 167 H), Mâlik ibn Anas (w. 179 H), Husyaim ibn Basyîr (w. 188 H), Jarîr ibn 'Abd al-Hamîd (w. 188 H), 'Abdullâh ibn al-Mubârak (w. 181 H), 'Abdullâh ibn Wahb 
(197 H), Wakî‘ ibn al-Jarrâh (w. 197 H), Sufyân ibn 'Uyainah (w. 198 H), dan Muhammad ibn Idrîs al-Syâfíiiy (w. 204 H). ${ }^{22}$

Proses penyebaran dan transmisi hadis mencapai puncaknya pada abad III H yang dianggap sebagai masa paling cemerlang atau era keemasan dalam sejarah perkembangan hadis. $^{23}$ Sepanjang abad ini

22 Muhammad ibn Ja'far alKattâniy, al-Risâlat al-Mustathrafah, (Beirut: Dâr al-Kutub al-'Ilmiyyah, 1400 H), h. 8; Muhammad ibn Mathar al-Zahrâniy, Tadwîn al-Sunnat alNabawiyyah, (Thaif: Maktabat alShadîq, 1412 H), h. 88-89; Muhammad Muhammad Abû Syuhbah, Fî̀ Rihâab al-Sunnat al-Kutub al-Shihâh $\underline{h}$ al-Sittah, (Kairo: Majma' al-Buhûts alIslâmiyyah, 1389 H/1969 M), h. 23-24; Mushthafâ al-Sibâ'iy, al-Sunnat wa Makânatuhâ fî al-Tasyrî‘ al-Islâmiy, (Kairo: Dâr al-Qaumiyyat li al-Thibâ'at wa al-Nasyr, 1368 H/1949 M), h. 103; al-Nu'mân 'Abd al-Muta'âl al-Qâdliy, al- $\underline{\text { Hadîts }}$ al-Syarîf: Dirâyatan wa Riwâyatan, (Kairo: al-Majlis al-A'lâ li al-Syu'ûn al-Islâmiyyah, 1395 H/1975 M), h. 30-31; Muhammad 'Ajjâj alKhathîb, Ushûl al-Hadîts, h. 182; Muhammad 'Ajjâj al-Khathîb, alSunnat Qabl al-Tadwîn, h. 337-338; Muhammad Abû Zahwu, al- $\underline{\text { Hadîts wa }}$ al-Muhadditsûn, h. 244; 'Abd al-'Azîz al-Khûliy, Miftâh al-Sunnat, h. 21; Muhammad Abû Syuhbah, al-Wasîth fî 'Ulûm, h. 71; Jamâl al-Dîn al-Qâsimiy, Qawâ 'id al-Tahdîts, 70.

23 Akram Dliyâ' al-'Umariy, Buhûts fî Târîkh al-Sunnat al- sejumlah besar ulama hadis terlibat aktif dalam kegiatan periwayatan hadis dan sebagian mereka telah membukukannya dalam karya-karya kompilasi standar yang dikenal dengan "alKutub al-Sittah"-yakni Shahîh al-Bukhâriy, Shahîh $\underline{h}$ Muslim, Sunan Abî Dâwud, Jâmi' alTirmidziy, Sunan al-Nasâ'iy, dan Sunan Ibn Mâjah-ataupun dalam karya-karya kompilasi hadis lainnya. ${ }^{24}$ Pasca abad III $\mathrm{H}$, penyebaran dan transmisi hadis, terutama yang bersifat lisan (al-riwâyat alsyafahiyyah), sudah jauh lebih

Musyarrafah, (Madinah: Maktabat al'Ulûm al-Hikam, 1415 H/1994 M), h. 308; Muhammad Abû Syuhbah, Fî Rihâab al-Sunnat, h. 27; Muhammad ibn Mathar al-Zahrâniy, Tadwîn alSunnat, h. 93; Mushthafâ al-Sibâ'iy, alSunnaț wa Makânatuhâ, h. 103; Nûr alDîn 'Itr, Manhaj al-Naqd, h. 61; Muhammad Abû Syuhbah, al-Wasîth fî 'Ulûm, h. 73-74.

${ }^{24}$ Shubhiy al-Shâlih, 'Ulûm al-Hadîts wa Mushthalahuhu, (Beirut: Dâr al-'Ilm li al-Malâyîn, 1988 M), h. 48; Muhammad ibn Ja'far al-Kattâniy, al-Risâlat al-Mustathrafah, h. 9-10; Muhammad ibn Mathar al-Zahrâniy, Tadwîn al-Sunnat, $\quad$ h. 97-143; Muhammad Abû Syuhbah, Fî Rihâab al-Sunnat, h. 27-28; Mushthafâ alSibâ'iy, al-Sunnat wa Makânatuhâ, h. 103-104; Muhammad Abû Syuhbah, al-Wasith fì 'Ulûm, h. 73-74; 'Abd al'Azîz al-Khûliy, Miftâh al-Sunnaț, h. 33-34. 
berkurang dan kemudian mengalami masa surut. ${ }^{25}$

\section{Tradisi Rihlah Ilmiah dalam Arus Penyebaran dan Transmisi Hadis}

Rihlah ilmiah pada dasarnya merujuk pada setiap perjalanan untuk menuntut ilmu, mencari tempat belajar yang baik, mencari guru yang lebih otoritatif, atau juga perjalanan seorang ilmuwan ke berbagai tempat, apakah dia secara formal melakukan aktivitas akademik atau tidak. Dengan demikian, rihlah ilmiah bisa mencakup sebuah perjalanan yang memang direncanakan untuk tujuan ilmiah (belajar, mengajar, berdiskusi, mencari kitab, dan seterusnya), atau sekadar perjalanan biasa yang dilakukan oleh orang-orang yang terlibat dalam kegiatan keilmuan. ${ }^{26}$

Tradisi rihlah ilmiah dalam konteks pencarian hadis

25 Mushthafâ al-Sibâ'iy, alSunnat wa Makânatuhâ, h. 104; Akram Dliyâ' al-'Umariy, Buhûts fî Târîkh alSunnat, h. 308; M; 'Abd al-'Azîz alKhûliy, Miftâh al-Sunnat, h. 34; Syuhudi Ismail, Pengantar Ilmu Hadis, h. 120 .

${ }^{26}$ Hasan Asari, Menguak
Sejarah Mencari 'Ibrah:
Sejarah Sosial-Intelektual
Klasik, (Bandung: Citapustaka Media,
2006), h. 198.

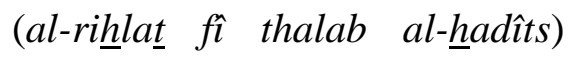
tumbuh sejalan dengan meluasnya domain kekuasaan Islam ke luar batas-batas wilayah Arabia. Para sarjana hadis awal telah datang dari berbagai kota yang jauh untuk memperoleh pengetahuan mengenai hadis. Saat itu rihlah dianggap lebih mulia daripada terbenam dalam kenyamanan mempelajari buku-buku (kitâbah). ${ }^{27}$ Dalam rihlahnya, mereka rela tidak tidur sepanjang malam, menempuh perjalanan yang jauh, mengarungi padang pasir yang gersang, dan memasuki berbagai negeri. Di tengah keterbatasan bekal dan sulitnya transportasi, mereka layak dicatat sebagai ulama yang terus abadi di sepanjang masa. ${ }^{28}$

Secara historis, tradisi rihlah tersebut diawali oleh perjalanan keilmuan yang dilakukan oleh para sahabat Nabi saw. untuk mencari hadis. Jâbir ibn 'Abdillâh (w. 78 H), misalnya, ketika sampai kepadanya sebuah hadis yang konon berasal dari salah seorang sahabat Nabi saw., ia pun

\footnotetext{
${ }^{27}$ Munawar Ahmad Anees dan Alia N. Athar, Guide to Sira and Hadith, h. xix.

${ }^{28}$ Muhammad Abû Syuhbah, Fî Rihâhb al-Sunnat, h. 23.
} 
membeli unta, lalu mengadakan perjalanan dengan mengendarai unta itu selama satu bulan hingga sampai di negeri Syria. Ternyata sahabat dimaksud adalah 'Abdullâh ibn Unais. Jâbir pun menanyakan langsung hadis itu kepadanya. ${ }^{29}$ Sahabat lainnya, Abû Ayyûb al-Anshâriy (w. $52 \mathrm{H}$ ) juga mengadakan perjalanan dari Madinah ke Mesir untuk mencari sebuah hadis dari 'Uqbah ibn 'Âmir. Sementara itu, Abû al-Dardâ' (w. $32 \mathrm{H})$ memberikan pernyataan, "Seandainya aku mendapati kesulitan memahami ayat al-Qur'an, tetapi tidak ada yang dapat membantu memecahkannya kecuali seseorang yang tinggal di Birk

${ }^{29}$ Abû 'Amr Yûsuf ibn 'Abd al-Barr al-Namariy al-Qurthubiy alAndalusiy, Jâmi' Bayân al-'Ilm wa Fadllih, (Beirut: Dâr al-Kutub al'Ilmiyah, t.th.), juz I, h. 93; Abû Bakr Ahmad ibn 'Aliy ibn Tsâbit al-Khathîb al-Baghdâdiy, al-Kifâyat fì 'Ilm alRiwâyah, (Beirut: Dâr al-Kutub al'Ilmiyah, 1409 H/1988 M), h. 402.

30 al-Hâkim Abû 'Abdillâh

Muhammad ibn 'Abdillâh al-Hâfidz alNaisâbûriy, Ma'rifat 'Ulûm al-Hadîts, (Hyderabad: Dâirat al-Ma'ârif al'Utsmâniyah, t.th.), h. 7-8; Ibn 'Abd alBarr, Jâmi ' Bayân al-'Ilm, juz I, h. 9394; al-Khathîb al-Baghdâdiy, alKifâyațfì 'Ilm al-Riwâyah, h. 402.
al-Ghimâd, ${ }^{31}$ tentu aku akan mengadakan perjalanan ke sana."32

Selama periode tabiin, perjalanan keilmuan untuk mencari hadis semakin gencar dilakukan oleh para ulama hadis. Sa'îd ibn Musayyab (w. 94 H), misalnya, telah mengadakan perjalanan siang dan malam selama beberapa hari untuk mendapatkan sebuah hadis. ${ }^{33}$ Abû Qilâbah (w. $104 \quad \mathrm{H}$ ) mengaku pernah tinggal selama tiga hari di Madinah untuk

${ }^{31}$ Birk al-Ghimâd paling tidak menunjuk pada dua tempat: (1) sebuah tempat yang letaknya jauh di belakang kota Makkah; dan (2) suatu daerah yang berada di negeri Yaman. Menurut Ibn al-Dumainah, yang dimaksud Birk al-Ghimâd dalam pernyataan Abû Dardâ' tadi adalah sebuah daerah yang letaknya paling jauh di Yaman. Lihat Abû 'Abdillâh Yâqût ibn 'Abdillâh alHamawiy al-Rûmiy al-Baghdâdiy, Mu jam al-Buldân, (Beirut: Dâr alKutub al-'Ilmiyah, t.th.), juz I, h. 475.

32 al-Khathîb al-Baghdâdiy, al-Rihlat fì Thalab al-Hadîts, (Beirut: Dâr al-Kutub al-'Ilmiyah, 1395 H/1975 M), h. 195; Yâqût ibn 'Abdillâh alHamawiy, Mu 'jam al-Buldân, juz I, h. 475.

33 al-Khathîb al-Baghdâdiy, al-Rihlat fî̀ Thalab al-Hadîts, h. 127129; al-Khathîb al-Baghdâdiy, alKifâyat fì 'Ilm al-Riwâyah, h. 402; Ibn 'Abd al-Barr, Jâmi' Bayân al-'Ilm, juz I, h. 94; al-Hâkim al-Naisâbûriy, 'Ulûm al-ㅂadîts, h. 7-8 
bertemu dengan seseorang yang memiliki hadis agar dia dapat meriwayatkan hadis darinya. ${ }^{34}$ Hasan al-Bashriy (w. $110 \mathrm{H}$ ) juga mengadakan perjalanan dari Bashrah ke Kufah menemui $\mathrm{Ka}^{\prime} \mathrm{ab}$ ibn 'Ujrah untuk menanyakan suatu masalah. ${ }^{35}$ Busr ibn 'Ubaidillâh alHadlramiy (w. $110 \mathrm{H}$ ) mengaku pernah berkelana ke Mesir untuk mendengarkan sebuah hadis. ${ }^{36}$ Demikian juga, al-Zuhriy (w. $124 \mathrm{H})$ pernah melakukan pengembaraan ke Syria menjumpai 'Athâ' ibn Yazîd, Ibn Muhairîz, dan Ibn Haiwah, lalu ke Mesir, Irak, dan negerinegeri Islam lainnya untuk mencari hadis. $^{37}$ Aktivitas

34 al-Dârimiy, Sunan al-
Dârimiy, jilid I, h. 140; al-Khathîb alBaghdâdiy, al-Rihlat fî Thalab alHadîts, h. 144-145.

35 al-Khathîb al-Baghdâdiy,

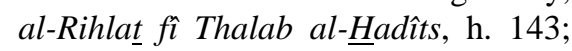
al-Khathîb al-Baghdâdiy, al-Kifâyat fì 'Ilm al-Riwâyah, h. 402; Akram Dliyâ' al-'Umariy, Buhûts fî Târîkh al-Sunnat, h. 279.

36 al-Dârimiy, Sunan alDârimiy, jilid I, h. 140; al-Khathîb alBaghdâdiy, al-Rihlat fî Thalab alHadîts, h. 147-148; Ibn 'Abd al-Barr, Jâmi' Bayân al-'Ilm, juz I, h. 95; Akram Dliyâ' al-'Umariy, Buhûts fî̀ Târîkh al-Sunnat, h. 279-280.

37 al-Hasan ibn 'Abd al-

Rahmân al-Râmahhurmuziy, alMuhaddits al-Fâshil baina al-Râwiy wa al-Wâ'iy, (Beirut: Dâr al-Fikr, 1404 serupa pernah dilakukan oleh 'Âmir al-Sya'biy, ${ }^{38}$ Makhûl, ${ }^{39}$ Abû al-'Âliyah, ${ }^{40}$ dan Ibn alDailamiy.

Sejak abad II H hingga beberapa abad setelahnya, perjalanan ilmiah mencari hadis menjadi fenomena yang sangat umum. Seperti diungkapkan Muhammad Mustafa Azami, "Thus from the second century to a few centuries later a general requirement of a student of hadith was to make extensive journeys for learning hadith". ${ }^{42}$ Selama beberapa abad ini, banyak ulama yang melakukan perjalanan dari negeri asalnya menuju berbagai negeri Islam

H/1984 M), h. 231; 'Âdil Muhammad Muhammad Darwîsy, Nazhrât fì al-

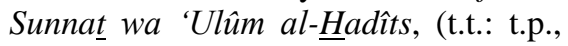
1419 H/1998 M), h. 91.

38 al-Khathîb al-Baghdâdiy, al-Rihlat fî Thalab al-Hadîts, h. 142; al-Khathîb al-Baghdâdiy, al-Kifâyat fî 'Ilm al-Riwâyah, h. 402; Ibn 'Abd alBarr, Jâmi ' Bayân al- 'Ilm, juz I, h. 95.

39 al-Khathîb al-Baghdâdiy, al-Rihlat fî̀ Thalab al-Hadîts, h. 198.

40 al-Dârimiy, Sunan alDârimiy, jilid I, h. 140; al-Khathîb alBaghdâdiy, al-Kifâyat fì 'Ilm alRiwâyah, h. 402-403; Akram Dliyâ' al'Umariy, Buhûts fî Târîkh al-Sunnat, h. 280.

41 al-Khathîb al-Baghdâdiy,

al-Rihlat fî̀ Thalab al-Hadîts, h. 135.

${ }_{42}$ Muhammad Mustafa

Azami, Studies in Hadith Methodology, h. 50 . 
lainnya untuk mendapatkan suatu hadis. Al-Auzâ'iy (w. 157 H) yang berasal dari Beirut mengadakan perjalanan menuju Yahyâ ibn Abî Katsîr yang berada di Yamamah, selanjutnya memasuki kota Bashrah. ${ }^{43}$

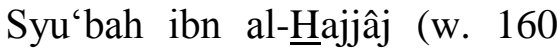
$\mathrm{H})$, ketika mengecek sebuah hadis, mengadakan perjalanan ke Makkah untuk menjumpai 'Abdullâh ibn 'Athâ'. Ibn 'Athâ' ternyata mendapatkan hadis itu dari Sa'ad ibn Ibrâhîm. Syu'bah pun mengadakan perjalanan ke Madinah untuk menemui $\mathrm{Sa}^{6} \mathrm{ad}$. Ternyata hadis itu diterima Sa'ad dari Ziyâd ibn Mikhraq. Maka Syu'bah melanjutkan perjalanan ke Bashrah untuk menemui Ziyâd. Ziyâd ternyata menerima hadis itu dari Syahr ibn Hausyab dari Abû Raihanah dari 'Uqbah ibn 'Âmir dari Nabi saw. ${ }^{44}$ Sufyân al-Tsauriy (w. 161 H) telah melakukan perjalanan dari Kufah ke Bashrah, lalu ke Yaman, untuk mendapatkan suatu hadis. ${ }^{45}$ Al-Syâfi'iy (w.

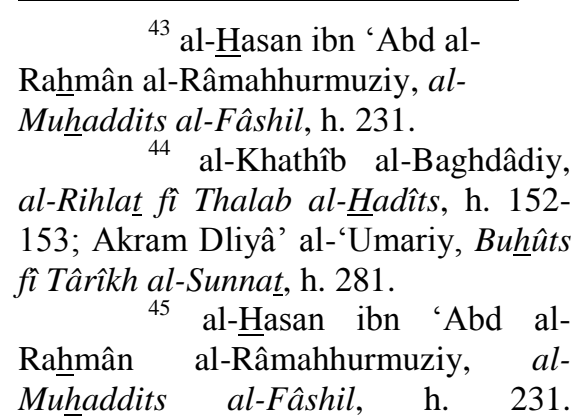

$204 \mathrm{H})$ pernah mengadakan perlawatan untuk mencari hadis yang ada pada Mâlik ibn Anas (w. $179 \mathrm{H})$ di Madinah, kemudian ke Baghdad dan Mesir. ${ }^{46}$

Demikian pula, Ahmad ibn Hanbal (w. $241 \mathrm{H}$ ), pernah melawat dan mengumpulkan hadis yang ada di Irak, Yaman, Kufah, Bashrah, Jazirah, Makkah, Madinah, dan Syria. ${ }^{47}$

Dilaporkan pula, Sufyân al-Tsauriy pernah berkelana ke Khurasan, Rayy, Jurjan, Palestina, Tha'if, dan Makkah. Lihat 'Ishâm Muhammad al-Hajj 'Aliy, al-Imâm Sufyân ibn Sa îd al-Tsauriy:

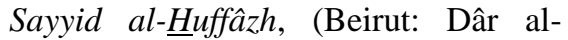
Kutub al-'Ilmiyah, 1412 H/1992 M), h. 61-65.

46 Jamâl al-Dîn 'Abd alRahîm al-Asnawiy, Thabaqât alSyâfi 'iyyah, (Beirut: Dâr al-Kutub al'Ilmiyah, 1407 H/1987 M), juz I, 18; Ahmad ibn 'Aliy ibn Hajar al'Asqalâniy, Sîrat al-Imâmain al-Laitsiy wa al-Syâfi 'iy, (Kairo: Matabat alÂdâb, 1415 H/1994 M), 117-121; Abû al-'Abbâs Syams al-Dîn Ahmad ibn Muhammad ibn Abî Bakr ibn Khallikân, Wafayât al-A 'yân wa Anbâ' Abnâ' al-Zamân, (Beirut: Dâr alTsaqâfah, t.th.), jilid IV, h. 165.

$$
47 \text { al-Hasan ibn 'Abd al- }
$$

Rahmân al-Râmahhurmuziy, alMuhaddits al-Fâshil, h. 230; Abû alFaraj 'Abd al-Rahmân ibn al-Jauziy, Manâqib al-Imâm A hrmad ibn Hanbal, (Beirut: Dâr al-Afâq al-Jadîdah, 1402 H/1982 M), h. 22; Muhammad Abû Zahrah, Ibn Hanbal, (Kairo: Dâr al- 
Al-Bukhâriy (w. 256 H), juga berkelana dan mengumpulkan hadis yang tersebar di berbagai daerah, seperti Makkah, Madinah, Syria, Mesir, Baghdad, Kufah, Bashrah, Wasith, Merv, Hara', Jazirah, Naisabur, 'Asqalan, Homsh, dan Khurasan. $^{48}$ Al-Hâkim alNaisâbûriy (w. 405 H) telah mengembara ke Irak, Khurasan, Transoxiana, dan Hijaz, untuk tujuan yang sama. ${ }^{49}$ Sementara al-Khathîb al-Baghdâdiy (w. 463 $\mathrm{H})$ pernah mengadakan perjalanan mencari hadis dari Baghdad ke daerah-daerah lain, seperti Kufah, Bashrah, Naisabur, Syria, Makkah, dan lainnya. ${ }^{50}$

Fikr al-'Arabiy, 1418 H/1997 M), h. 23-24.

Hâsyim, ${ }^{48}$ al-Husain 'Abd al-Majîd

Muhadditsan wa Faqîhan, (Kairo: Dâr al-Qaumiyah, t.th.), h. 28-36; Carl Brockelmann, Târîkh al-Adab al'Arabiy, terj. 'Abd al-Halîm al-Najjar, (Kairo: Dâr al-Ma‘ârif, 1977), juz III, h. 163.

49 Tâj al-Dîn Abî Nashr 'Abd al-Wahhâb ibn 'Aliy ibn 'Abd al-Kâfiy al-Subkiy, Thabaqât al-Syâfi iyyat alKubrâ, (Mesir: 'Îsâ al-Babiy al-Halabiy wa Syurakah, 1385 H/1966 M), juz IV, h. 156; al-Sayyid Mu'zham Husain, "Tadzikarat al-Mushannif”, dalam alHâkim al-Naisâburiy, 'Ulûm al- $\underline{H} a d i ̂ t s$, h. c.

${ }^{50}$ Abû Bakr Ahmad ibn 'Aliy ibn Tsâbit al-Khathîb al-Baghdâdiy,
Perjalanan keilmuan tersebut, selain tentu untuk mendapatkan hadis sebagai tujuan utamanya, juga dapat mendatangkan sejumlah manfaat. Pertama, untuk pengokohan dari sisi ilmiah. Sebuah perjalanan ilmiah mesti dilakukan dalam upaya menuntut ilmu agar dapat memperoleh sejumlah manfaat dan kesempurnaan ketika bertemu langsung dengan beberapa guru serta bergaul dengan banyak orang. ${ }^{51}$ Kedua, untuk penyebaran ilmu yang telah dihasilkan oleh ulama. Rihlah ilmiah yang dilakukan oleh seorang ulama menjadi salah satu sebab bagi kemunculan ilmu dan sekaligus penyebarannya ke berbagai daerah. Ketiga, untuk perluasan budaya masyarakat Islam. Ketika mengadakan pengembaraan ilmiah ke berbagai negeri, para ulama dapat mengadakan kontak

Jâmi ' li Akhlâq al-Râwiy wa Âdâb alSâmi', (Beirut: Mu'asasat al-Risâlah, 1401 H/1981 M), jilid I, h. 30-36.

51 Dalam kasus ini, Ibn Khaldûn berkomentar, "Bahwasanya perjalanan mencari berbagai ilmu dan menemui sejumlah guru dapat menambah kesempurnaan dalam pembelajaran." Lihat 'Abd Rahmmân ibn Khaldûn, Muqaddimat Ibn Khaldûn, (Beirut: Dâr al-Fikr, t.th.), h. 541. 
dengan orang-orang yang beragam budaya dan tradisi, yang kemudian terjadi pertukaran budaya ketika para ulama pengembara berpindah dari satu negeri ke negeri lainnya. Keempat, untuk menumbuhkan keutamaan dan kesempurnaan jiwa. Hal itu justru yang dicari oleh para ulama dalam pengembaraannya. Kelima, untuk mendapatkan sahabat-sahabat baru yang tulus. Rihlah ilmiah ternyata menjadi sarana efektif untuk mendapatkan kawan-kawan baru yang saling kenal dan sayang. Karenanya antar sesama muslim terjalin rasa sayang dan kerjasama yang tinggi, sehingga seluruh negeri Islam terbuka bagi setiap orang yang beragama Islam. ${ }^{52}$

Lebih lanjut, Akram Dliyâ' al-'Umariy menyatakan bahwa sekiranya bukan karena al-rihlat fì thalab al-'ilm (rihlah ilmiah untuk mencari hadis), maka yang akan muncul adalah corak pemikiran yang bersifat kedaerahan pada setiap kota di dunia Islam karena adanya

52 Nûr al-Dîn 'Itr, "I'jâz alNubuwwat al-'Ilmiy", dalam alKhathîb al-Baghdâdiy, al-Rihlat fî Thalab al- $\underline{\text { Hadits, }}$ h. 24-28. Bandingkan dengan Hasan Asari, Menguak Sejarah, h. 207-210. isolasi ilmiah. Akan tetapi, para ulama dengan senang hati melakukan pengembaraan ilmiah ke berbagai daerah dan sekaligus menimba ilmu dari pusat-pusat pemikiran yang berbeda-beda di dunia Islam. ${ }^{53}$ Segaris dengan al-'Umariy, Shubhiy al-Shâlih, mengungkapkan bahwa dampak dari perjalanan keilmuan mencari hadis adalah berupa penyatuan nas hadis dan mengubah wataknya dari corak kedaerahan ke corak umum yang universal. ${ }^{54}$

Dalam kegiatan rihlah ilmiah dan transmisi hadis itu terbangun jalinan hubungan yang erat antarsesama ulama hadis dari berbagai kota dan negeri, yang pada gilirannya membentuk semacam "jaringan ulama" yang luas di antara mereka. Pola hubungan yang terjadi dalam "jaringan ulama" itu jika diskemakan dapat saja mengambil bentuk hubungan antara guru dan murid, antara guru hadis yang satu dengan yang lainnya, maupun antarsesama murid yang

53 Akram Dliyâ' al-'Umariy, Buhûts fî Târîkh al-Sunnat, h. 284.

54 Shubhiy al-Shâlih, 'Ulûm

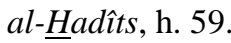


meriwayatkan hadis dari guru yang sama. ${ }^{55}$

\section{Kontribusi Transmisi Hadis dalam Pembentukan Jaringan Ulama}

\begin{tabular}{llr}
\multicolumn{2}{c}{ Jaringan } & ulama \\
merupakan hubungan yang & kompleks dan luas, baik yang \\
korjalin antarsesama ulama & antara ulama yang \\
maupun antara & \\
berfungsi sebagai guru dengan
\end{tabular}

55 Dalam penelitian dan studi hadis dikenal adanya istilah al-i'tibâr, yakni menyertakan seluruh mata-rantai transmisi (sanad) untuk matan hadis tertentu. Untuk lebih mudahnya biasanya dibuat sebuah skema. Dari situ akan terlihat dengan jelas seluruh jalur sanad yang diteliti, nama-nama periwayat, dan metode transmisi yang digunakan. Selain itu, dalam skema sanad yang menyeluruh akan tergambar dengan jelas hubungan guru dan murid, sesama guru, ataupun sesema murid yang menerima hadis dari guru yang sama. Penjelasan tentang al-i'tibâr ini, lihat Abû 'Amr 'Utsmân ibn 'Abd al-Rahmân ibn alShalâh al-Syahrzuriy, 'Ulûm al-Hadîs, (Madinah: al-Maktabat al-'Ilmiyyah, 1972), h. 74-76; Jalâl al-Dîn alSuyûthiy, Tadrîb al-Râwiy, h. 205; Mahmûd al-Thahhân, Taisir

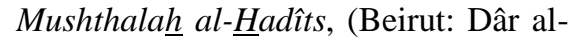
Qur'ân al-Karîm, 1399 H/1979 M), h. 140; M. Syuhudi Ismail, Metodologi Penelitian Hadis Nabi, (Jakarta: Bulan Bintang, 1413 H/1992 M), h. 51-52. murid-muridnya. ${ }^{56}$ Proses terbentuknya jaringan ulama secara umum terkait erat dengan perkembangan tradisi keilmuan Islam sendiri. Dalam konteks ini barangkali hadis merupakan cabang ilmu yang secara khusus memiliki peran istimewa. Seperti telah disinggung sebelumnya, dalam studi dan transmisi hadis terdapat sebuah tradisi keilmuan yang dikenal dengan "al-rihlat fi thalab alhadîts" (rihlah ilmiah untuk mencari hadis).

Azyumardi Azra dan Oman Fathurrahman menyetujui bahwa tradisi rihlah ilmiah secara historis bermula dari perjalanan keilmuan yang dilakukan oleh para sahabat sepeninggal Nabi saw. untuk mengumpulkan dan merekam hadis yang ditinggalkannya. Dalam perkembangan lebih lanjut, perjalanan keilmuan tersebut ternyata tidak hanya menghasilkan koleksi hadis, tetapi juga mendorong terbentuknya semacam "jaringan" sahabat Nabi saw. yang terlibat dalam usaha

${ }^{56}$ Azyumardi Azra dan Oman Fathurrahman, "Jaringan Ulama", h. 105. 
merekam, menghafal, dan mencatat hadis. ${ }^{57}$

Setelah generasi sahabat berlalu dan persoalan pengumpulan serta perekaman hadis diambil alih oleh generasi tabiin, jarak yang diperlukan dalam perjalanan keilmuan tersebut menjadi semakin jauh seiring dengan meluasnya wilayah kekuasaan Islam dan bertambahnya jumlah pusatpusat ilmu pengetahuan. Maka jadilah perjalanan keilmuan dalam rangka mencari hadis, mengumpulkan, menyeleksi, menilai, dan kemudian mengkodifikasikannya sebagai wujud awal tradisi rihlah ilmiah dalam sejarah Islam. ${ }^{58}$

Ketika hadis telah terkumpul dan dihimpun dalam karya-karya kompilasi hadis yang otoritatif, perjalanan keilmuan tersebut tidak lagi terjadi dalam konteks pengumpulan hadis, tetapi lebih jauh dalam upaya menuntut dan mengembangkan ilmu-ilmu keislaman secara keseluruhan. ${ }^{59}$

${ }^{57}$ Azyumardi Azra dan Oman Fathurrahman, "Jaringan Ulama", h. 105.

Sejarah, h. 201.

58 Hasan Asari, Menguak

59 Azyumardi Azra dan Oman Fathurrahman, "Jaringan Ulama", h. 105.
Sejarah intelektual Islam klasik dengan jelas menunjukkan bahwa para ulama pada semua bidang keilmuan turut melakukan rihlah ilmiah. ${ }^{60}$ Dalam studi sejarah, misalnya, tercatat nama al-Balâdzuriy (w. $279 \mathrm{H}$ ), yang pernah melakukan rihlah ke Aleppo, Damaskus, Homs, Antiokia, Irak, dan kota lainnya. ${ }^{61}$ Sejarawan lainnya, alYa'qûbiy (w. 284 H), pernah mengembara ke Armenia, Transoxania, Zanjan, Azerbaijan, Hamadzan, Isfahan, Naisabur, Merv, Badighistan, Sijistan, Balkh, Bukhara, Samarkand, Makkah, Madinah, Yaman, Aljazair, Homsh, Syria, Yordania, Aleppo, India, Mesir, Palestina, Libya, Tunisia, Maroko, Spanyol, dan negeri lainnya. $^{62}$ Al-Thabariy (w. 310 H) melakukan rihlah ilmiah dari

${ }^{60}$ Hasan Asari, Menguak

Sejarah, h. 201.

61 Ridlwân Muhammad

Ridlwân, "Hayât al-Balâdzuriy", dalam Abû alBuldân, (Beirut: Dâr al-Kutub al'Ilmiyah, 1412 H/1991 M), h. 7.

${ }^{62}$ Husain 'Âshiy, al-Ya 'qûbiy: 'Ashruh, Sîrat Hayâtih, Manhajuh alTârîkhiy, (Beirut: Dâr al-Kutub al'Ilmiyah, 1413 H/1992 M), h. 42-43; Yusri Abd al-Ghani Abdullah, Historiografi Islam: Dari Klasik hingga Kontemporer, terj. Sudrajat, (Jakarta: Raja Grafindo Persada, 2004), h. 169-176. 
kota kelahirannya, Thibristan, menuju Baghdad, lalu ke Mesir, Syria, dan Irak. ${ }^{63}$ Al-Mas'ûdiy berkelana dari Baghdad menuju Mesir, kemudian ke Persia, Kerman, India, Srilangka, Oman, Zanzibar, pesisir Afrika Timur, Sudan, Madagaskar, Jurjan (Georgia), Syria, Palestina, dan Antiokia. ${ }^{64}$ Rihlah ini akhirnya mencapai hasil mengagumkan di tangan Ibn Baththûthah (w. 779 H). Ia mengembara ke berbagai penjuru dunia. Selama 30 tahun mengembara, ia menempuh perjalanan lebih dari 75.000 mil. ${ }^{65}$ Negeri-negeri yang pernah disinggahinya adalah Marokko, Aljazair, Tunisia, Libya, Mesir, Palestina, Lebanon, Syria, Hijaz, Yaman, Oman, Bahrain, India,

63 'Effat al-Sharqawi, Filsafat Kebudayaan Islam, terj. Ahmad Rofi' Usmani, (Bandung: Pustaka, 1406 H/1986 M), h. 269.

${ }^{64}$ Husain Âshiy, Abû $a l$ Husain al-Mas 'ûdiy: al-Mu'arrikh wa al-Jughrâfiy, (Beirut: Dâr al-Kutub al'Ilmiyah, 1413 H/1993 M), h. 50-51; Shukrieh R. Merlet, "Arab Historiography", dalam Mohamed Taher (ed.), Encyclopaedic Survey of Islamic Culture, (New Delhi: Anmol Publications Pvt. Ltd., 1997), vol. V, h. 85; 'Effat al-Sharqawi, Filsafat Kebudayaan Islam, h. 285.

65 Jamil Ahmad, Hundred Great Muslims, (Lahore, Rawalpindi, Karachi: Ferozsons Ltd., 1984), h. 500.
Khurasan, Turkistan, Afghanistan, Srilangka, Cina, Fez, Spanyol, Gibraltar, Sudan, dan lainnya. ${ }^{66}$

Perjalanan keilmuan yang sama juga ditempuh oleh para ulama sufi. Seorang sufi terkemuka, Abû Hâmid alGhazâliy (w. 505 H), dari kota kelahirannya, Thus, pernah mengembara ke Jurjan (Georgia), Naisabur, Baghdad, Damaskus, Yerusalem, Makkah, Madinah, dan Hamadzan. ${ }^{67}$ Sufi lainnya, Ibn 'Arabiy (w. $638 \mathrm{H}$ ), pernah mengembara ke Sevilla, Ceuta, Rota, Tunisia, Fez, Mesir, Makkah, Madinah, Yerusalem, Baghdad, Mosul, Ronda, Konya, Damaskus, Hebron, Aleppo, Armenia, dan beberapa kota lainnya untuk menjumpai para guru sufi. ${ }^{68}$ Pengembaraan

66 Asmâ' Abû Bakr

Muhammad, Ibn Baththûthah: al-Rajul wa al-Rihlah, (Beirut: Dâr al-Kutub al'Ilmiyah, 1412 H/1992 M), h. 39-41.

$$
67 \text { Abdul Fattah Sayyid }
$$

Ahmad, Tasawuf Antara al-Ghazali \& Ibn Taimiyah, terj. Muhammad Muchson Anasy, (Jakarta: Khalifa, 2005), h. 57-61; Osman Bakar, Hierarki Ilmu: Membangun RangkaPikir Islamisasi Ilmu Menurut alFarabi, al-Ghazali, Quthb al-Din alSyirazi, terj. Purwanto, (Bandung: Mizan, 1997), h. 181-188.

68 Claude Addas, Mencari Belerang Merah: Kisah Hidup Ibn 'Arabi, terj. Zaimul Am, (Jakarta: 
seperti ini sudah sangat lazim di kalangan sufi. Para ulama fikih, tafsir, kalam, atau lainya, juga sering melakukan rihlah untuk mendapatkan ilmu. Perjalanan para sarjana muslim dari berbagai latar belakang keilmuan tersebut pada gilirannya membentuk jaringan ulama di kalangan mereka.

Lebih jauh, pembentukan jaringan ulama dan keilmuan dalam Islam tampaknya tak dapat dipisahkan dari sistem jaringan sanad (isnâd) yang sangat dipentingkan dalam transmisi hadis. Sebagaimana diketahui, studi dan transmisi hadis melibatkan serangkaian otoritas yang dikenal dengan "sanad" (isnâd). Sanad merupakan mata-rantai transmisi yang berkesinambungan sampai kepada Nabi Muhammad saw. ${ }^{69}$

Serambi, 2004), h. 167-312; Kautsar Azhari Noer, Ibn al- 'Arabi: Wahdat alWujûd dalam Perdebatan, (Jakarta: Paramadina, 1995), h. 19-24.

69 Penjelasan tentang sanad (isnâd), menurut para sarjana hadis, lihat Zhafar Ahmad al-'Utsmâniy alTahânawiy, Qawâ'id fì 'Ulûm alHadîts, Kairo: Dâr al-Salâm, 1421 H/2000 M), h. 26; Mahmud alThahhan, Ushûl al-Takhrîj wa Dirâsat al-Asânîd, (Riyadl: Maktabat alMa'ârif, 1412 H/1991 M), h.138; Muhammad Mathar al-Zahrâniy, 'Ilm al-Rijâl: Nasy'atuhu wa Târîkhuhu, (Riyadl: Dâr al-Hijrah, 1417 H/1996
Dalam perkembangan historis lebih lanjut, terutama pada masa pertumbuhan jaringan ulama, sanad ini mengacu pada rangkaian sejumlah guru dengan murid-muridnya yang menerima pelajaran tentang ilmu hadis. ${ }^{70}$

Oleh karena itu, dalam proses penyebaran dan transmisi hadis terbentuk sebuah jaringan yang dikenal dengan "jalur sanad" (al-thuruq), yakni suatu jalinan yang menghubungkan antara guru dan murid. ${ }^{71}$ Predikat dan jalinan hubungan guru dan murid dalam kasus transmisi hadis ini barangkali cukup lentur. Seorang periwayat suatu saat diposisikan sebagai murid ketika ia menerima hadis dari periwayat sebelumnya, namun ia juga dapat dipandang sebagai guru ketika menyampaikan hadis kepada orang lain. ${ }^{72}$ Bahkan, tak jarang terjadi pertukaran posisi ketika

M), h. 15-16; Mahmûd al-Thahhân, Taisir Mushthalah al-Hadîts, h. 15; Muhammad 'Ajjâj al-Khathîb, Ushûl al- $\underline{\text { H}}$ adîts, h. 32 .

${ }^{70}$ Azyumardi Azra dan Oman

Fathurrahman, "Jaringan Ulama", h.

106.

${ }^{71}$ Ibrâhîm Dasûkiy al-

Syahâwiy, Mushthalah al- $\underline{\text { Hadîts, h. }}$.

68.

${ }^{72}$ Ibrâhîm Dasûkiy al-

Syahâwiy, Mushthalah al- $\underline{\text { Hadits, }}$ h. 68. 
para periwayat saling meriwayatkan hadis satu sama lain.

Sistem jaringan sanad (isnâd), dengan demikian, mendorong terbentuknya jaringan ulama di kalangan para ahli hadis. Secara faktual, sebuah hadis terkadang ditransmisikan melalui banyak "jalur sanad" (al-thuruq). Dengan adanya jalur sanad yang banyak itu sudah cukup untuk melahirkan semacam jaringan ulama di antara para periwayat hadis. Apalagi, jika hadis yang ditransmisikan dalam jumlah yang lebih besar, maka akan tersusun jaringan ulama hadis yang lebih luas. Kalau sekiranya para sarjana hadis rata-rata mentransmisikan hadis dalam jumlah puluhan, ratusan, atau ribuan, tentu akan terbentuk jaringan ulama yang sangat kompleks dan ekstensif. Dalan jaringan itu mungkin sekali terjadi hubungan saling silang di antara banyak ulama yang terlibat dalam transmisi hadis. ${ }^{73}$

\footnotetext{
${ }^{73}$ Penjelasan yang lebih luas tentang penyebaran jaringan sanad hadis, lihat Muhammad Mustafa Azami, Studies in Hadith Methodology, h. 33-42; G.H.A. Juynboll, "Some Isnâd -Analytical Methods Illustrated on the Basis of Several Women Demeaning Sayings from Hadith Literature", dalam G.H.A. Juynboll,
}

Dalam perspektif sejarah ilmu-ilmu keislaman, sistem jaringan sanad (isnâd) ini juga diterapkan dalam berbagai cabang keilmuan, seperti tafsir, fikih, dan sejarah Islam. Sebagai misal, dalam bidang tafsir terdapat sebuah corak penafsiran yang lebih mementingkan matarantai transmisi, yang dikenal dengan tafsîr bi al-ma'tsûr atau tafsîr bi al-riwâyah. ${ }^{74}$ Demikian pula, dalam studi sejarah Islam, ditemukan model historiografi dengan al-riwâyah. ${ }^{75}$ Sementara itu, studi fikih pada masa awalnya juga sangat mengandalkan sanad karena fikih semula memang merupakan bagian yang tak terpisahkan dari hadis. ${ }^{76}$

Studies on the Origins and Uses of Islamic Hadith, (Aldershot: Variorum, 1996), h. 343-383.

74 Muhammad Husain alDzahabiy, al-Tafsîr wa al-Mufassirûn, (Kairo: Maktabat Wahbah, 1424 H/2003 M), juz I, h. 11; Muhammad 'Aliy al-Shâbûniy, al-Tibyân fî̀ 'Ulûm al-Qur'ân, (Beirut: 'Âlam al-Kutub, 1405 H/1985 M), h. 67.

75 'Effat al-Sharqawi, Filsafat

Kebudayaan Islam, h. 259. Muhammad Zubayr Shiddiqi, "Hadith—A Subject of Keen Interest", dalam P.K. Koya (ed.), Hadith and Sunnah: Ideals and Realities, (Kuala Lumpur: Islamic Book Trust, 1996), h. 13. 
Selain itu, penggunaan sanad (isnâd) yang lebih luas ditemukan dalam tarekat. Sistem jaringan sanad dalam tarekat disebut dengan "silsilah". Silsilah tarekat berkesinambungan satu sama lain ke atas sampai kepada Nabi saw. atau bahkan sampai kepada Malaikat Jibril dan Allah swt. yang merupakan sumber dari segala pengetahuan spiritual. $^{77}$ Sebagaimana halnya sanad dalam hadis, silsilah yang berkesinambungan merupakan salah satu syarat terpenting bagi kesahihan otoritas dalam keilmuan dan penerimaan tasawuf atau tarekat sehingga tarekat tersebut dapat dipandang sah $\quad$ (mu'tabarah) ${ }^{78}$ Silsilah tarekat ini juga turut membentuk jaringan ulama dan keilmuan dalam Islam.

${ }^{77}$ Azyumardi Azra dan Oman Fathurrahman, "Jaringan Ulama", h. 106.

78 Gambaran umum tentang silsilah atau jaringan guru-murid dalam beberapa tarekat maktabarah, antara lain dapat dilihat dalam Sri Mulyati et al., Mengenal dan Memahami Tarekattarekat Muktabarah di Indonesia, (Jakarta: Kencana, 2005), h. 26-397; Zamakhsyari Dhofir, Tradisi Pesantren: Studi tentang Pandangan Hidup Kyai, (Jakarta: LP3ES, 1994), h. 79-81; Endang Turmudi, Perselingkuhan Kiai dan Kekuasaan, (Yogyakarta: LKiS, 2004), h. 73-90.
Studi

disertasi

Azyumardi Azra yang membahas tentang jaringan ulama Timur Tengah dan Melayu-Nusantara pada abad XVII dan XVIII $M$ juga menegaskan bahwa sanad hadis dan silsilah tarekat mempunyai peranan signifikan dalam menghubungkan para ulama yang terlibat dalam jaringan. Melalui telaah-telaah hadis, para guru dan murid-murid dalam jaringan ulama terkait satu sama lain. Demikian pula, organisasi tarekat, melalui silsilah yang berkesinambungan, menjadi sarana untuk menghubungkan ulama satu sama lainnya. ${ }^{79}$

Lepas dari pentingnya sanad dan sisilah sebagai faktor penting yang menimbulkan keterpaduan dalam jaringan ulama, pada dasarnya jaringan ulama yang terbetuk dan berkembang sepanjang sejarah Islam tidaklah terorganisasi secara formal, apalagi menjadi sebuah organisasi formal tertentu. Jaringan antara mursyid dan wakil mereka memang seringkali terjalin melalui kerangka organisasi terekat,

${ }^{79}$ Azyumardi Azra, Jaringan Ulama Timur Tengah dan Kepulauan Nusantara Abad XVII dan XVIII, (Bandung: Mizan, 1994), h. 105-107, 295. 
tetapi jaringan antarmereka tidak terorganisasi secara formal. Karenanya jaringan ulama lebih merupakan ikatan yang bersifat longgar dan informal, tetapi karena berbagai faktor ikatan itu menjadi cukup solid dan efektif dalam mencapai tujuan keilmuan Islam khususnya dan penyebaran Islam umumnya. ${ }^{80}$

\section{PENUTUP}

Dari pemaparan di muka terungkap dengan jelas bahwa proses pembentukan jaringan intelektual dan keilmuan dalam Islam berkaitan erat dengan perkembangan historis penyebaran dan transmisi hadis maupun tradisi al-rihlat fí thalab al-hadîts (rihlah ilmiah untuk mencari hadis). Dalam arus penyebaran dan transmisi hadis terjadi pola hubungan yang kompleks dan saling silang antara guru dan murid, sesama guru, ataupun sesama murid, yang kemudian membentuk semacam "jaringan ulama" yang terdiri atas para sarjana hadis. Sebagaimana diketahui, proses transmisi hadis melibatkan rangkaian otoritas yang berkesinambungan sampai kepada Nabi Muhammad saw.

${ }^{80}$ Azyumardi Azra dan Oman Fathurrahman, "Jaringan Ulama", h. 106. yang dikenal dengan "sanad"

(isnâd). Dari proses transmisi hadis inilah terbentuk sebuah jaringan yang dikenal dengan "jalur sanad" (al-thuruq), yakni suatu jalinan yang menghubungkan antara guru dan murid. Dalam perkembangan selanjutnya, khususnya pada masa pertumbuhan jaringan ulama, jalur sanad mengacu kepada rangkaian sejumlah guru dengan murid-muridnya yang menerima pelajaran tentang ilmu hadis.

Sistem jaringan sanad (isnâd) tersebut kemudian diterapkan dalam berbagai cabang disiplin ilmu keislaman, seperti tafsir, fikih, dan sejarah Islam. Dalam bidang tafsir terdapat sebuah corak penafsiran yang lebih mementingkan matarantai transmisi, yang dikenal dengan tafsîr bi al-ma'tsûr atau tafsîr bi al-riwâyah. Dalam studi sejarah Islam, ditemukan model historiografi dengan al-riwâyah. Penggunaan sanad juga ditemukan dalam bidang fikih. Jaringan sanad (isnâd) yang lebih luas dijumpai dalam tarekat yang dikenal dengan "silsilah". Silsilah tarekat berkesinambungan satu sama lain ke atas sampai kepada Nabi saw. atau bahkan sampai kepada Malaikat Jibril dan Allah swt. 
Jaringan sanad dan silsilah tarekat ini juga turut membentuk jaringan ulama dan keilmuan dalam Islam.

Tradisi al-rihlat fi thalab al-hadîts (rihlah ilmiah untuk mencari hadis) yang tumbuh bersamaan dengan proses penyebaran dan transmisi hadis juga diakui memberikan kontribusi penting dalam pembentukan jaringan ulama dan keilmuan dalam Islam. Secara historis, tradisi rihlah ilmiah bermula dari perjalanan keilmuan yang dilakukan oleh para sahabat sepeninggal Nabi saw. untuk mengumpulkan dan merekam hadis yang ditinggalkannya. Perjalanan keilmuan tersebut pada gilirannya bukan hanya menghasilkan koleksi hadis, tetapi juga mendorong terbentuknya semacam "jaringan" sahabat Nabi saw. yang terlibat dalam usaha merekam, menghafal, dan mencatat hadis. Setelah sahabat, para sarjana hadis dari generasi tabiin, atbâ' al-tâbi 'în, dan seterusnya juga giat melakukan perjalanan keilmuan untuk mengumpulkan dan merekam hadis yang kemudian membentuk semacam "jaringan ulama" di antara mereka. Ketika hadis telah terkumpul dan dihimpun dalam karya-karya kompilasi hadis yang otoritatif, perjalanan ilmiah tidak lagi terjadi dalam konteks pengumpulan hadis, tetapi lebih jauh dalam upaya menuntut dan mengembangkan ilmu-ilmu keislaman secara keseluruhan, mulai bidang tafsir, fikih, kalam, tasawuf, hingga sejarah Islam. Perjalanan para ulama dari berbagai latar belakang keilmuan pada gilirannya membentuk jaringan ulama di kalangan mereka.

\section{DAFTAR PUSTAKA}

\author{
Abdullah, Taufik et al. (ed.). \\ Ensiklopedi Tematis \\ Dunia Islam. Jilid V. \\ Jakarta: Ichtiar Baru Van \\ Hoeve, 2005.
}

Abdullah, Yusri Abd al-Ghani. Historiografi Islam: Dari Klasik hingga Kontemporer. Terj. Sudrajat. Jakarta: Raja Grafindo Persada, 2004.

Abû Syuhbah, Muhammad ibn Muhammad. al-Wasîth fî 'Ulûm wa Mushthala $\underline{h}$ al-hadits. Kairo: Maktabat al-Sunnah, 1427 H/2006 M. 
- Fî Rihâb al-

Sunnat al-Kutub al-

Shihâh al-Sittah. Kairo:

Majma' al-Buhûts al-

Islâmiyyah,

1389

H/1969 M.

Abû Zahrah, Muhammad. Ibn Hanbal. Kairo: Dâr alFikr al-'Arabiy, 1418 H/1997 M.

Abû Zahwu, Muhammad Muhammad. al- $\underline{\text { Haditts }}$ wa al-Muhadditsûn. Mesir: Dâr al-Fikr al'Arabiy, 1376 H.

Addas, Claude. Mencari Belerang Merah: Kisah Hidup Ibn 'Arabi. Terj. Zaimul Am. Jakarta: Serambi, 2004.

Ahmad, Abdul Fattah Sayyid. Tasawuf Antara alGhazali \& Ibn Taimiyah. Terj. Muhammad Muchson Anasy. Jakarta: Khalifa, 2005.

Ahmad, Jamil. Hundred Great Muslims. Lahore, Rawalpindi, Karachi: Ferozsons Ltd., 1984.

Agusyanto, Ruddy. Jaringan Sosial dalam Organisasi.
Jakarta: Raja Grafndo Persada, 2007.

'Aliy, 'Ishâm Muhammad alHajj. al-Imâm Sufyân ibn Saîd al-Tsauriy: Sayyid al-ㅍuffâzh. Beirut: Dâr al-Kutub al'Ilmiyah, 1412 H/1992 M.

Anees, Munawar Ahmad dan Alia N. Athar. Guide to Sira and Hadith Literature in Western Language. London: Manshell Publishing Limited, 1986.

Asari, Hasan. Menguak Sejarah Mencari 'Ibrah: Risalah Sejarah SosialIntelektual Muslim Klasik. Bandung: Citapustaka Media, 2006.

'Âshiy, Husain. al-Ya'qûbiy: 'Ashruh, Sîrat Hayâtih, Manhajuh al-Târîkhiy. Beirut: Dâr al-Kutub al'Ilmiyah, 1413 H/1992 M.

Abû al- $\underline{\text { Husain }}$ al-Mas 'udiy: alMu'arrikh wa alJughrâfiy. Beirut: Dâr 
al-Kutub al-'Ilmiyah, 1413 H/1993 M.

al-Asnawiy, Jamâl al-Dîn 'Abd al-Rahîm. Thabaqât alSyâfi 'iyyah. Juz I. Beirut: Dâr al-Kutub al'Ilmiyah, 1407 H/1987 M.

al-'Asqalâniy, Ahmad ibn 'Aliy ibn Hajar. Sîrat alImâmain al-Laitsiy wa al-Syâfi ‘iy. Kairo: Matabat al-Âdâb, 1415 H/1994 M.

Azami, Muhammad Mustafa. Studies in Hadith Methodology and Literature. Indianapolis: Islamic Teaching Center, 1997. . Manhaj al-Naqd 'inda al-Muhadditsîn: Nas'atuhu wa Târîkhuhu. Saudi Arabia: Maktabat alKautsar, 1410 H/ 1990 M.

Azra, Azyumardi. Jaringan Ulama Timur Tengah dan Kepulauan Nusantara Abad XVII dan XVIII. Bandung: Mizan, 1994.
Fathurrahman. "Jaringan Ulama", dalam Taufik Abdullah et al. (ed.). Ensiklopedi Tematis Dunia Islam. Jilid V. Jakarta: Ichtiar Baru Van Hoeve, 2005.

al-Baghdâdiy, Abû Bakr Aḥmad ibn 'Aliy ibn Tsâbit alKhathîb. al-Kifâyat fí 'Ilm al-Riwâyah. Beirut: Dâr al-Kutub al'Ilmiyah, 1409 H/1988 M.

Thalab al-Hadîts. Beirut: Dâr al-Kutub al'Ilmiyah, 1395 H/1975 M.

Jâmi‘ li Akhlâq al-Râwiy wa Âdâb alSâmi'. Beirut: Mu'asasat al-Risâlah, 1401 H/1981 M.

Bakar, Osman. Hierarki Ilmu: Membangun RangkaPikir Islamisasi Ilmu Menurut al-Farabi, alGhazali, Quthb al-Din al-Syirazi. Terj. Purwanto. Bandung: Mizan, 1997. 


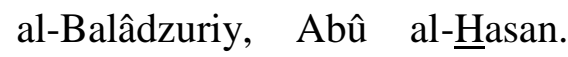
Futûh al-Buldân. Beirut: Dâr al-Kutub al'Ilmiyah, 1412 H/1991 M.

Brockelmann, Carl. Târîkh alAdab al-'Arabiy. Terj.

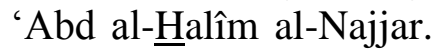
Juz III Kairo: Dâr alMa‘ârif, 1977.

Brown, Daniel W. Rethinking Tradition in Modern Islamic Thaught. Cambridge: Cambridge University Press, 1994.

al-Dârimiy, 'Abdullâh ibn 'Abd al-Rahmân alSamarqandiy. Sunan alDârimiy. Jilid I. Beirut: Dâr al-Fikr, t.th.

Darwîsy, 'Âdil Muhammad Muhammad. Nazhrât fî̀ al-Sunnat wa 'Ulûm alHadîts. T.t.: t.p., 1419 H/1998 M.

Dhofir, Zamakhsyari. Tradisi Pesantren: Studi tentang Pandangan Hidup Kyai. Jakarta: LP3ES, 1994.

al-Dzahabiy, Muhammad Husain. al-Tafsîr wa alMufassirûn. Juz I. Kairo:
Maktabat Wahbah, 1424 H/2003 M.
al-Hâkim, Abû 'Abdillâh Muhammad ibn 'Abdillâh al-Hâfidz al- Naisâbûriy. Ma'rifat 'Ulûm al- $\underline{\text { Hadîts. }}$ Hyderabad: Dâirat al- Ma'ârif al-'Utsmâniyah, t.th.

al- Hamawiy, Abû 'Abdillâh Yâqût ibn 'Abdillâh alRûmiy al-Baghdâdiy. Mu'jam al-Buldân. Beirut: Dâr al-Kutub al'Ilmiyah, t.th.

Hâsyim, Aḥmad 'Umar. Qawầid Ushûl alHadîts. Beirut: Dâr alFikr, t.th.

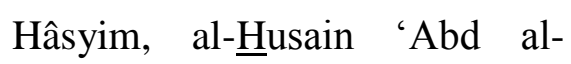
Majîd. al-Imâm alBukhâriy Muhadditsan wa Faqîhan. Kairo: Dâr al-Qaumiyah, t.th.

Husain, al-Sayyid Mu'zham. "Tadzikarat alMushannif", dalam alHâkim Abû 'Abdillâh Muhammad ibn 'Abdillâh al-Hâfidz alNaisâbûriy. Ma'rifat

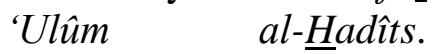
Hyderabad: Dâirat al- 
Ma'ârif al-'Utsmâniyah, t.th.

Ibn 'Abd al-Barr, Abû 'Amr Yûsuf al-Namariy alQurthubiy al-Andalusiy. Jâmi 'Bayân al-'Ilm wa Fadllih. Juz I. Beirut: Dâr al-Kutub al'Ilmiyah, t.th.

Ibn al-Jauziy, Abû al-Faraj 'Abd al-Rahmân. Manâqib alImâm Ahmad ibn Hanbal. Beirut: Dâr alAfâq al-Jadîdah, 1402 H/1982 M.

Ibn Khaldûn, 'Abd Rahmân. Muqaddimat Ibn Khaldûn. Beirut: Dâr alFikr, t.th.

Ibn Khallikân, Abû al-'Abbâs Syams al-Dîn A ibn Muhammad ibn Abî Bakr. Wafayât al-A'yân wa Anbâ' Abnâ' alZamân. Jilid IV. Beirut: Dâr al-Tsaqâfah, t.th.

Ibn al-Shalâh, Abû 'Amr 'Utsmân ibn 'Abd alRahmân al-Syahrzuriy.

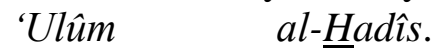
Madinah: al-Maktabat al-'Ilmiyyah, 1972.
Ismail, M. Syuhudi. Kaedah Kesahihan Sanad Hadis: Telaah Kritis dan Tinjauan dengan Pendekatan Ilmu Sejarah. Jakarta: Bulan Bintang, 1415 H/1995 M.

Metodologi Penelitian Hadis Nabi. Jakarta: Bulan Bintang, 1413 H/1992 M. Pengantar Ilmu Hadits. Bandung: Angkasa, 1991.

'Itr, Nûr al-Dîn. Manhaj alNaqd fì 'Ulûm al-ㅂadîts. Damaskus: Dâr al-Fikr, 1418 H/1997 M.

Manâhij alMuhadditsîn al- 'Âmmah. Damaskus: Maktabat Dâr al-Furûq, 1420 H/1999 M.

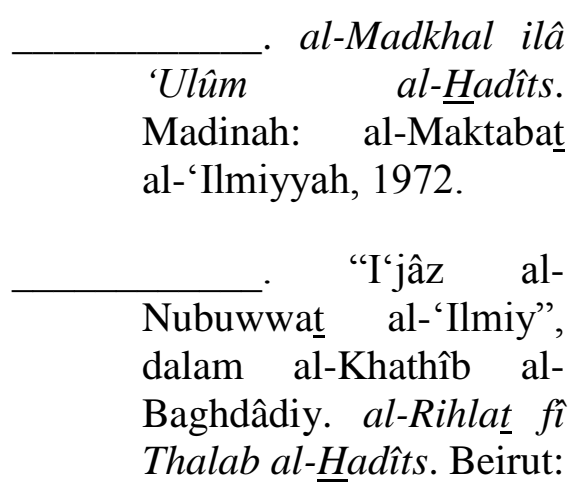


Dâr al-Kutub al'Ilmiyah, 1395 H/1975 M.

Jabali, Fu'ad. The Companions of The Prophet: A Geographical

Distribution and Political Alignments. Leiden: Brill, 2003.

al-Jawâbiy, Muhammad Thâhir. Juhûd al-Muhadditsîn fî̀ Naqd Matn al-Hadîts alNabawiy al-Syarîf. T.t.: Mu'assasât 'Abd alKarîm ibn 'Abdillâh, 1406 H/1986 M.

Juynboll, G.H.A. "Some Isnâd -Analytical Methods Illustrated on the Basis of Several Women Demeaning Sayings from Hadith Literature", dalam G.H.A. Juynboll. Studies on the Origins and Uses of Islamic Hadith. Aldershot: Variorum, 1996.

G.H.A. Studies on the Origins and Uses of Islamic Hadith. Aldershot: Variorum, 1996.

al-Kattâniy, Muhammad ibn Ja'far. al-Risâlat al-
Mustathrafah. Beirut: Dâr al-Kutub al'Ilmiyyah, $1400 \mathrm{H}$.

al-Khathîb, Muhammad 'Ajjâj. Ushûl al- $\underline{\text { Hadîts: }}$

'Ulûmuhu wa

Mushthalahuhu. Beirut:

Dâr al-Fikr, 1409

H/1989 M.

. al-Sunnat Qabl

al-Tadwîn. Beirut: Dâr al-Fikr, $1401 \mathrm{H} / 1981 \mathrm{M}$.

al-Khûliy, Muhammad 'Abd al'Azîz. Miftâh al-Sunnat au Târîkh Funûn alHadîts. Beirut: Dâr alKutub al-'Ilmiyyah, t.th.

Koya, P.K. (ed.). Hadith and Sunnah: Ideals and Realities. Kuala Lumpur: Islamic Book Trust, 1996.

Merlet, Shukrieh R. "Arab Historiography", dalam Mohamed Taher (ed.). Encyclopaedic Survey of Islamic Culture. Vol. V. New Delhi: Anmol Publications Pvt. Ltd., 1997.

Muhammad, Asmâ' Abû Bakr. Ibn Baththûthah: alRajul wa al-Rihlah. 
Beirut: Dâr al-Kutub al'Ilmiyah, 1412 H/1992 M.

Mulyati, Sri et al. Mengenal dan Memahami Tarekattarekat Muktabarah di Indonesia. Jakarta: Kencana, 2005.

Muslim, Abû al-Husain ibn alHajjâj al-Qusyairiy alNaisâbûriy. Shahîh Muslim. Kairo: Dâr Ibn al-Haitsam, 1422 H/2001 M.

Noer, Kautsar Azhari. Ibn al'Arabi: Wahdat alWujûd dalam Perdebatan. Jakarta: Paramadina, 1995.

al-Qâdliy, al-Nu'mân 'Abd al-

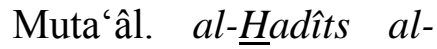
Syarîf: Dirâyatan wa Riwâyatan. Kairo: alMajlis al-A'lâ li alSyu'ûn al-Islâmiyyah, 1395 H/1975 M.

al-Qâsimiy, Muhammad Jamâl al-Dîn. Qawâ'id alTahdîts min Funûn Mushthalah al- $\underline{\text { Hadits. }}$. T.t.: Îsâ al-Halabiy, 1353 $\mathrm{H}$.
al-Qaththân, Mannâ‘. Mabâhits fì 'Ulûm al-Hadîts. Kairo: Maktabat Wahbah, 1425 H/2004 M.

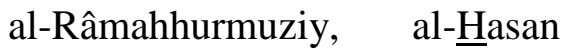
ibn 'Abd al-Rahmân. alMuhaddits al-Fâshil baina al-Râwiy wa alWâ'iy. Beirut: Dâr alFikr, 1404 H/1984 M.

Ridlwân, Ridlwân Muhammad. "Hayât al-Balâdzuriy", dalam Abû alBalâdzuriy, Futûh $\underline{h}$ lBuldân. Beirut: Dâr alKutub al-'Ilmiyah, 1412 H/1991 M.

al-Shâbûniy, Muhamammad. 'Aliy al-Tibyân fì 'Ulûm alQur'ân. Beirut: 'Âlam al-Kutub, 1405 H/1985 M.

al-Shâliḥ, Shubhiy. 'Ulûm alHadîts wa Mushthalahuhu. Beirut: Dâr al-'Ilm li alMalâyîn, 1988 M.

al-Sharqawi, 'Effat. Filsafat Kebudayaan Islam. Terj. Ahmad Rofi' Usmani. Bandung: Pustaka, 1406 H/1986 M. 
Shiddiqi, Muhammad Zubayr. "Hadith-A Subject of Keen Interest", dalam P.K. Koya (ed.). Hadith and Sunnah: Ideals and Realities. Kuala Lumpur: Islamic Book Trust, 1996.

al-Sibâ‘iy, Mushthafâ. al-Sunnat wa Makânatuhâ fî alTasyrî̀ al-Islâmiy. Kairo: Dâr al-Qaumiyyat li al-Thibâ'at wa alNasyr, 1368 H/1949 M.

al-Subkiy, Tâj al-Dîn Abî Nashr 'Abd al-Wahhâb ibn 'Aliy ibn 'Abd al-Kâfiy. Thabaqât al-Syâfi 'iyyat al-Kubrâ. Mesir: 'Îsâ alBabiy al-Halabiy wa Syurakah, 1385 H/1966 M.

al-Suyûthiy, Jalâl al-Dîn. Tadrîb al-Râwiy fî Syarh Taqrîb al-Nawâwiy. Kairo: Dâr al-ㅁadits, 1423 H/2002 M.

al-Syahâwiy, Ibrâhîm Dasûkiy.

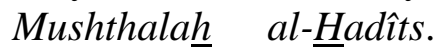
T.t.: Syirkat al-Thibâ'at al-Fanniyyat alMuttahidah, 1971.

al-Tahânawiy, Zhafar Ahmad al'Utsmâniy. Qawâ'id fì

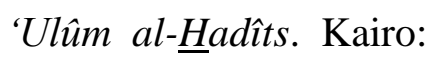

Dâr al-Salâm, 1421 H/2000 M.

al-Thahhân, Mahmûud. Taisir Mushthala $\underline{h}$ al- $\underline{\text { Hadîts. }}$ Beirut: Dâr al-Qur'ân alKarîm, 1399 H/1979 M.

Ushîl al-Takhrîj

wa Dirâsat al-Asânîd. Riyadl: Maktabat_ al-Ma'ârif, 1412 H/1991 M.

Turmudi, Endang. Perselingkuhan Kiai dan Kekuasaan. Yogyakarta: LKiS, 2004.

al-'Umariy, Akram Dliyâ' Buhûts fî Târîkh alSunnat al-Musyarrafah. Madinah: Maktabat al'Ulûm al-Hikam, 1415 H/1994 M.

Usmani, Justice Muhammad Taqi. The Authority of Sunnah. New Delhi: Kitab Bhavan, t.th.

al-Zahrâniy, Muhammad ibn Mathar. Tadwin alSunnat al-Nabawiyyah. Thaif: Maktabat alShadîq, 1412 H.

Nasy'atuhu Ilm al-Rijâl: wa 
Târîkhuhu. Riyadl: Dâr al-Hijrah, 1417 H/1996 $\mathrm{M}$ 